\title{
THE STORY OF THE ICY PARADISE: POLISH MIGRATION TO NORWAY AFTER THE EU ENLARGEMENT (2004) IN THE LIGHT OF RESEARCH AND STATISTICAL DATA

\author{
Katarzyna Gmaj ${ }^{1}$, Krystyna Iglicka ${ }^{2}$
}

\begin{abstract}
This paper highlights basic trends in migration outflows of Poles to Norway. It focuses on the fact that Polish migrants constitute the biggest group of immigrants in Norway and addresses the question regarding their geographical distribution. The authors analyse some theoretical approaches, statistical data and trends with special emphasis on the demographics of the Polish population in Norway in relation to the labour market and family behaviours. Furthermore, the analysis presented in this paper emphasizes that, along with the networks and growing number of children, a part of the temporary Polish migration into Norway has been transformed from circular migration into permanent migration. Therefore, adaptation of Polish migrants in Norway is better explained in terms of different stages in the migratory process rather than in terms of different categories of migrants. What is more, the process of pioneering male migration followed by a family reunification seems similar to that observed in Polish migration to the UK.
\end{abstract}

JEL Classification Numbers: J6, J1; DOI: http://dx.doi.org/10.12955/cbup.v6.1149

Keywords: migration, Norway, Poland, family, labour markets, economic crisis, migrant networks.

\section{Introduction}

The aim of this paper is to provide background evidence on the scale and nature of Polish family migration to Norway. This paper brings together previously published statistics, new, and vital findings from the Transfam project ${ }^{3}$, and some additional data and analysis on specific questions related to family migration. In the age of migration and mobility not only do many facets of contemporary family life take place against the backdrop of intensified movement in its various forms, but family practice is deeply embedded in migration and mobility (Castles et al., 2014; Astrom \& Westerlund, 2009; White, 2011).

The original economic model of migration does not differentiate between personal and family decisions. In the Sjaastad model (1962), the focus is placed upon the individual. There is no analysis of how migration by an individual may affect other persons close to him or her. Keeping the Transfam project in mind, the migration model mentioned above should be extended in order to take into account not only the effects of family on the migration decision but also the effects that the migration decision has on all members of the family or household. The conflicting interests and the family migration decision were studied by Polachek and Horvath (1977) and Mincer (1978). Their models recognise that individual family members can have conflicting interests. The family's migration may enhance the well-being of some family members but reduce the well-being of others. This means that while the household head's income and job satisfaction may improve with relocation, other family members may suffer psychological costs as a result of leaving family and friends behind, adjusting to a new language and culture, etc.

Most families are rooted in particular locations and show no interest in migration. However, when a family is impelled to move even though neither spouse is explicitly interested in it, research demonstrates that wife's human capital or search for employment have little effect on that decision. It is also worth mentioning that due to gendered family responsibilities (care for younger and older family members) women may be limited in their mobility even if they desire to migrate, although more recent research shows that increasingly more men are following their migrating wives or partners (Cooke, 2013).

\footnotetext{
${ }^{1}$ Lazarski University, Poland, k.gmaj@lazarski.edu.pl

${ }^{2}$ Lazarski University, Poland, k.iglicka@lazarski.edu.pl

${ }^{3}$ Project Transfam: Doing Family in Transnational Context, Polish-Norwegian Research Fund has received funding from the Polish-Norwegian Research Programme operated by the National Centre for Research and Development under the Norwegian Financial Mechanism 2009-2014 in the frame of Project Contract No PolNor/197905/4/2013. TRANSFAM research project is run by Jagiellonian University (leader) and its partners from the Polish-Norwegian consortium: Centre for International Relations, Agder Research, NOVA Oslo and Akershus University College of Applied Sciences
} 


\section{The growth of the Polish population in Norway}

Norway accepted a few thousand of Polish political refugees in the 1980s and gave employment to seasonal workers arriving in the 1990s on the basis of bilateral agreements on temporary work in agriculture. This pioneering migration to Norway definitely formed a seed of the Polish community in this country. Nowadays, Polish migrants constitute the biggest group of immigrants in Norway, standing at the beginning of 2018 at about 98.200 with an additional 12.300 Norwegian-born to Polish parents (Statistics Norway). They are distributed all over the country, however more than half of them reside in four counties (Akershus, Oslo, Rogeland, Hordaland). What is more, Poles are the largest group of immigrants in many Norwegian municipalities and they can be found even in small localities. Table 1 presents their geographical distribution. At this point it should be mentioned that the data included in this table does not refer to persons staying in Norway for a period of less than six months who are registered as non-resident wage earners.

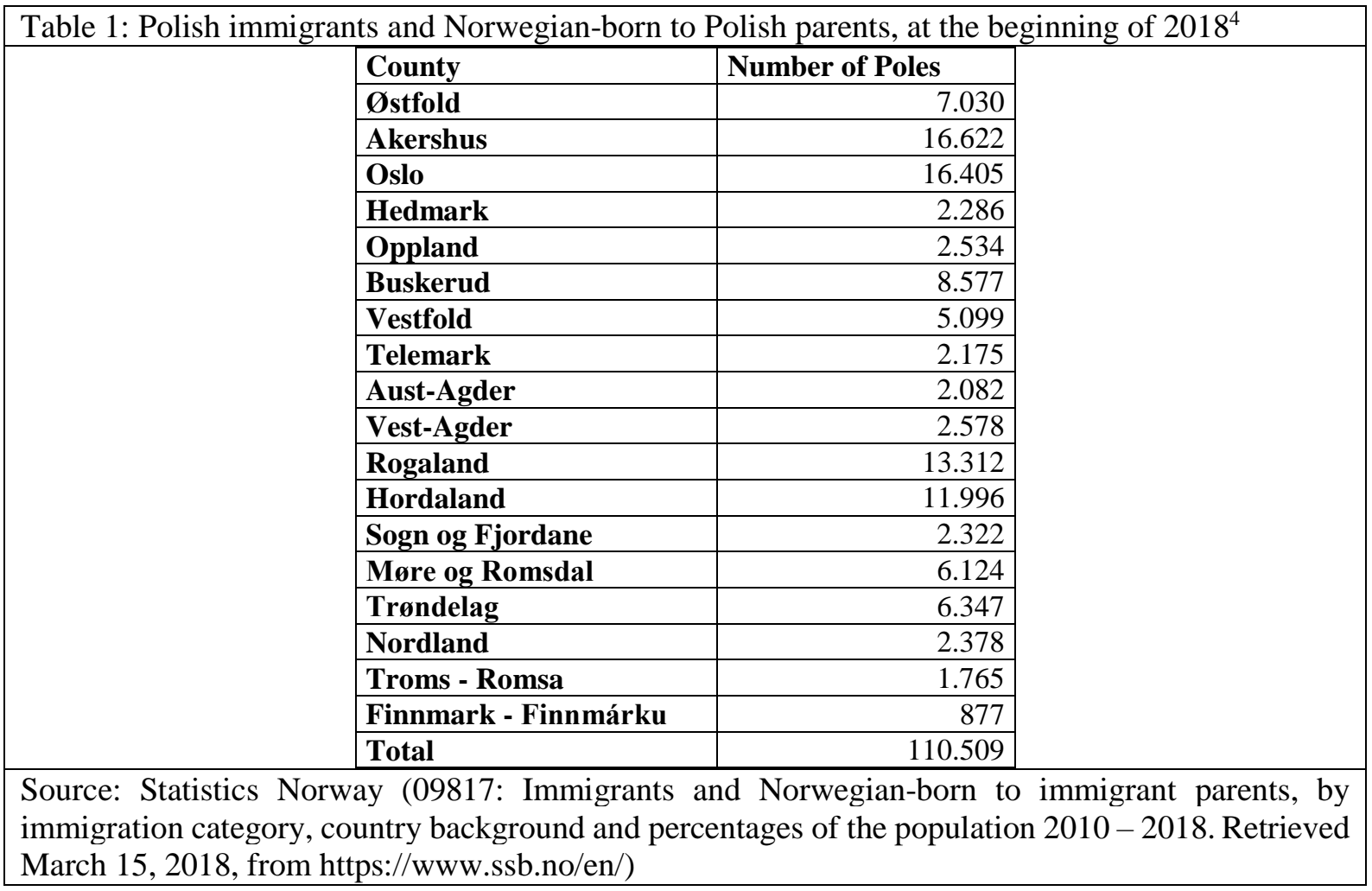

The growth of the Polish population in Norway after Poland's accession to the EU can be explained in terms of both push and pull-factors (Iglicka, Gmaj, Wierzejski, 2016). As far as pull-factors are concerned, the most visible incentive is the average gross hourly wage, which is several times higher than the Polish one - in 2007, the average gross hourly earnings in Norway was EUR 26, while in Poland EUR 3.3 (Friberg et al., 2012, p.157). In 2010, the gap between countries has slightly decreased but still was significant (Eurostat: Poland - EUR 4.0, Norway - EUR 25). This discrepancy is valued, especially when money is sent back to families remaining in Poland.

Aside from the total size of a population, the most important characteristic is its sex and age structure, or, in other words, the proportion of people at each age by sex. One should note that the sex-age structure determines potential for future growth of specific age groups and the total population. As it is shown in Table 2 and Figure 1, males significantly outnumber females among Polish immigrants and Norwegians born to immigrant parents. At the beginning of 2018, women constituted only 38 percent of Poles

\footnotetext{
${ }^{4}$ There are two definitions the Norwegians refer to, both in terms of statistics and more general in terms of studies on migration. The first definition is related with the term immigrants. Immigrants are persons born abroad with two foreign-born parents and four foreign-born grandparents. The second term used in Norway is Norwegian-born to immigrant parents. They are persons born in Norway of two parents born abroad, and in addition having four grandparents born abroad (Statistics Norway)
} 
residing in Norway. The lack of balance between sexes is even more evident, when non-residents are taken into consideration.

Table 2: Polish immigrants and Norwegian-born to Polish parents, by sex

\begin{tabular}{|l|c|l|l|l|l|l|l|l|l|l|}
\hline & $\mathbf{2 0 0 9}$ & $\mathbf{2 0 1 0}$ & $\mathbf{2 0 1 1}$ & $\mathbf{2 0 1 2}$ & $\mathbf{2 0 1 3}$ & $\mathbf{2 0 1 4}$ & $\mathbf{2 0 1 5}$ & $\mathbf{2 0 1 6}$ & $\mathbf{2 0 1 7}$ & $\mathbf{2 0 1 8}$ \\
\hline Males & 29.971 & 33.949 & 38.792 & 46.790 & 53.778 & 58.883 & 63.627 & 67.014 & 67.939 & 68.849 \\
\hline Females & 14.511 & 18.176 & 21.818 & 25.313 & 28.823 & 32.296 & 35.797 & 38.711 & 40.316 & 41.660 \\
\hline
\end{tabular}

Source: Statistics Norway (05183: Immigrants and Norwegian-born to immigrant parents, by sex and country background 1970 - 2018. Retrieved March 15, 2018, from https://www.ssb.no/en/)

Figure 1: Population pyramid - Polish Immigrants and Norwegian-born to immigrant parents at the beginning of 2018

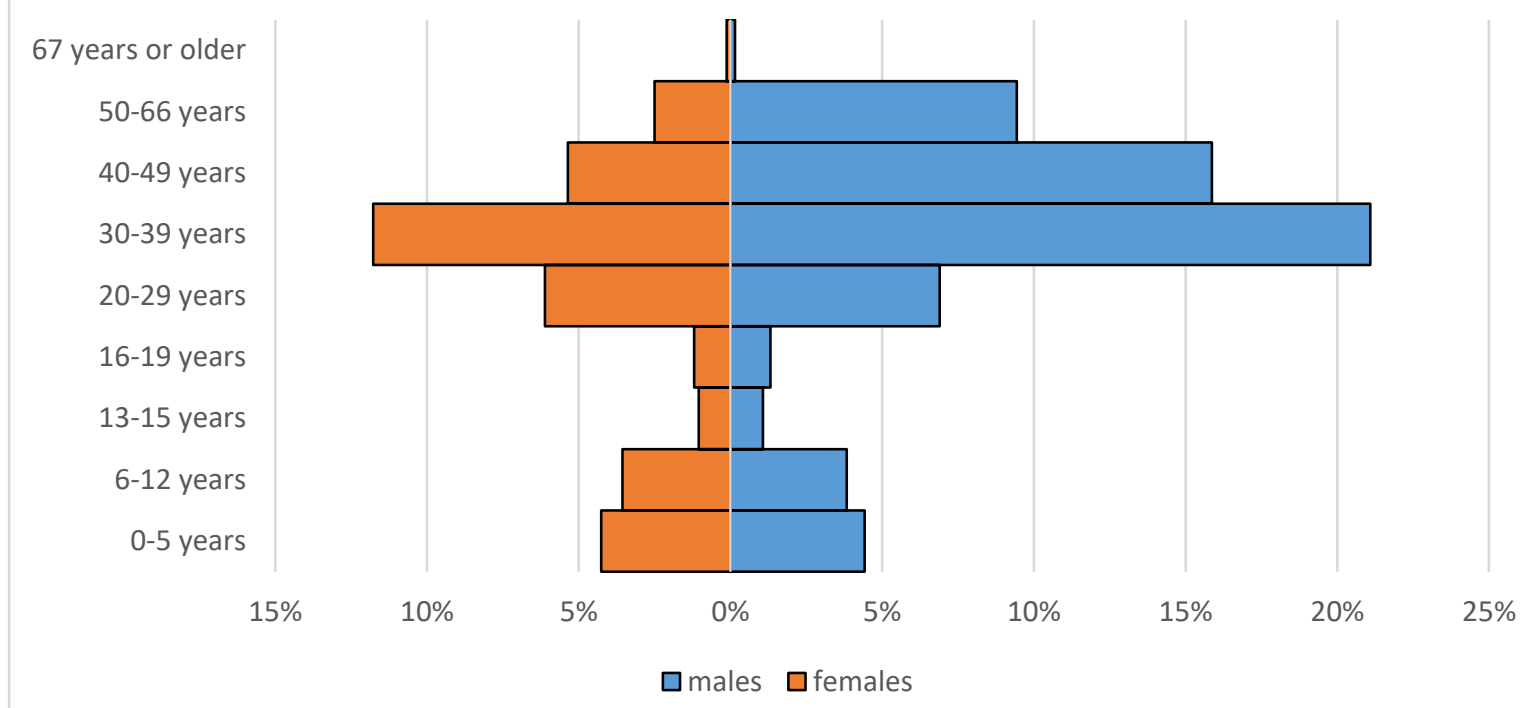

Source: Own elaboration based on Statistics Norway data (05196: Population, by sex, age and citizenship 1977 - 2018; Retrieved March 15, 2018, from https://www.ssb.no/en/).

Such a structure is partially a result of labour market demand, or more precisely, social and structural changes observed within the Norwegian labour market. The restructuration of labour intensive sectors, such as construction, and the increasing of the informalization and casualization of labour relations and their connection to international migration, have been elaborated in literature (e.g. Sassen, 2005). Another pull-factor is the boom in the Norwegian economy that has produced demand for labour in construction and manufacturing. This also explains the high share of male migrants. Furthermore, transitional restrictions for labour migrants originating from the new EU member states (valid till 2009), requiring full-time work at Norwegian wage in order to obtain the residence permit, could discourage women since these requirements were more difficult to fulfil in female-dominated labour sectors (Friberg et al., 2012).

Nevertheless, even after the restriction phased out and despite the fact that more women are registered as residents, the discrepancy in the gender ratios continues (see Figure 2). It seems that labour demand is the best explanation for this situation. Although migrant networks increase the accessibility of jobs to Polish women (Friberg, 2012b), the need for labourers undertaking the so called 'male' jobs is higher.

When the growth of Polish population is discussed, migrant networks should also be mentioned. As migration scholars noted, with the passage of time migration flows develop and the number of potential migrants increases. Migrant networks offer support in finding employment and accommodation. They reduce the economic and psychological costs and risks of international migration (Faist, 2002; Portes et al., 1999; Cohen \& Vertovec, 1999). The importance of location-specific capital (DaVanzo 1981) ${ }^{5}$ and social networks has been confirmed by Transfam's research as well. It was found that Polish post-EU

\footnotetext{
${ }^{5}$ The concept of location-specific capital focuses on the territorial limitation of the utility of resources accessible by individuals.
} 
accession migrants actively searched for jobs for their relatives and friends in order to help them escape their economic hardship in Poland. Increasingly, these labour migrants brought their relatives (family reunion), siblings, cousins, aunts, uncles, etc. They establish their families there or gather their family members, who used to live in Poland, they buy flats and houses, send their children to Norwegian kindergartens and schools (Gmaj, 2016; Gmaj, 2018).

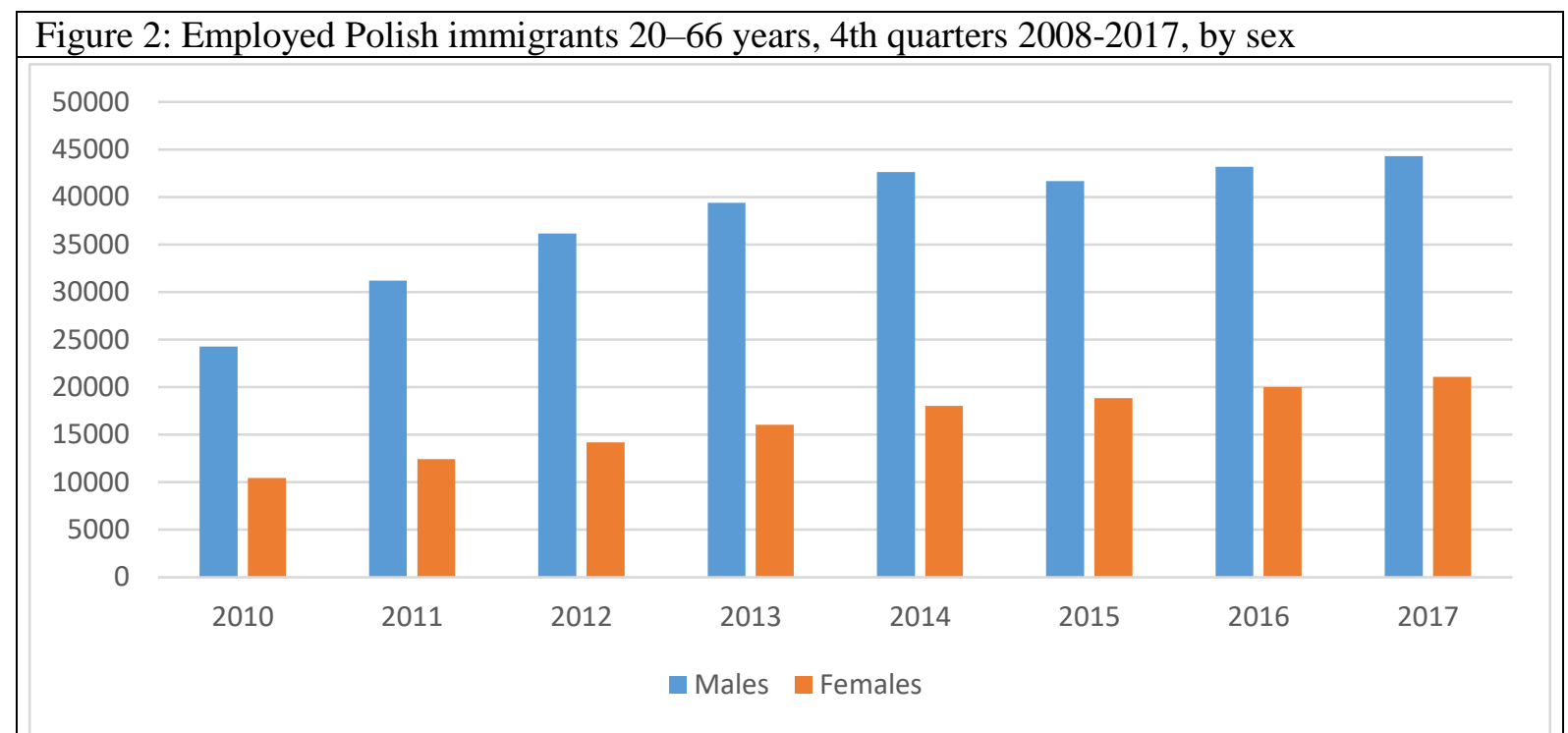

Source: Own elaboration based on Statistics Norway data (11609: Employed immigrants, by sex, age, country background and years of residence in Norway. 4th quarter 2008 - 2017. Retrieved March 15, 2018, from https://www.ssb.no/en/)

The analysis of Transfam's material shows that, similarly to the UK or Ireland (Iglicka, 2008; 2010; White, 2011), we are witnessing a process of settlement of Polish migrants in Norway. Regardless of the initial plans, these Polish migrants currently see their future in Norway, not in Poland (See: Gmaj 2016; 2018; Iglicka, Gmaj, Wierzejski, 2018).

An important indicator confirming the tendency for permanent settlement is the number of Poles indicating family reasons for their first entry to Norway. After 2009, a year that was especially harsh for Polish families in Norway due to the economic crisis that affected the Scandinavian countries (a decrease in statistics on family reunification from 4.423 in 2008 to 2.773 in 2009), a strong determination in reunification strategies has been visible again for the Polish group (4.612 in 2010). Members of Polish families constitute the largest group entering Norway for family reasons since 2006 (Thorud, 2014, p.16; 2018, p. 22) (see Table 4).

The number of naturalizations observed among Poles might serve as a next example of change from temporariness to permanent stay. However, it is important to consider that Polish citizens can reside and work in Norway on the basis of the free movement of workers, so their motivation for obtaining Norwegian citizenship is not strong. The number of naturalizations observed in 2010-2016 is not high, compared to the total population of Poles residing in Norway. Nevertheless, it had been growing from 50 in 2010 to 324 in 2014 and was kept above 200 in two following years (see Table 5).

Table 4: Family immigration from Poland to Norway. New resident permits and EEA-registrations, 2004-2016

\begin{tabular}{|l|c|c|r|r|r|r|r|r|r|r|r|r|r|}
\hline Year & 2004 & 2005 & 2006 & 2007 & 2008 & 2009 & 2010 & 2011 & 2012 & 2013 & 2014 & 2015 & 2016 \\
\hline & 390 & 748 & 1.702 & 3.292 & 4.423 & 2.773 & 4.612 & 4.376 & 4.516 & 4.687 & 4.291 & 3.655 & 2775 \\
\hline
\end{tabular}

Source: UDI (as cited in Thorud, 2014,p16; 2018, p.22 )

\begin{tabular}{|c|c|c|c|c|c|c|c|}
\hline Year & 2010 & 2011 & 2012 & 2013 & 2014 & 2015 & 2016 \\
\hline Number of persons & 50 & 80 & 138 & 166 & 324 & 241 & 276 \\
\hline
\end{tabular}

Source: Statistics Norway (04767: Naturalizations, by sex, age and earlier citizenship. Retrieved March 15, 2018, from https://www.ssb.no/en/) 
In conclusion, we should point out that it is justified to claim that former expectations related to the temporariness of Polish migration after 2004 can, at least to some extent, be questioned. More and more Poles decide on more permanent settlement instead of circulation between Norway and Poland. Although the latter group is still significant, as is shown in Table 3, the number of those who prolong their stay grows. It should be stressed that Transfam's findings confirm the results of earlier studies indicating that processes of migration and adaptation of Polish migrants in Norway are better explained in terms of different stages in the migratory process rather than in terms of different categories of migrants (Friberg, 2012a). Since migrants reshape their strategies according to circumstances, their initial plans might change. Those who circulate between Poland and Norway, at certain time might extend their stay in Norway and bring along their family members.

We discussed pull-factors that brought Polish migrants to Norway, but the questions arises: What keeps them there; and why do they end up planning permanent settlement? Transfam's research suggests that an economic factor is crucial (Iglicka et al., 2018; Gmaj 2016). In Norway immigrants have found a sense of security stemming from a clear rule: when one works, one receives sufficient remuneration to sustain his or her family. This outcome of Transfam's qualitative studies is also confirmed by Transfam's web survey in which 648 respondents were interviewed (see Table 6). The vast majority of respondents ( 85 percent) find their family situation after migration at least good and approximately 15 percent find it difficult to give a definite answer. Only six out of 648 respondents describe their family situation after migration as bad or very bad, which is less than 1 percent. Seven out of ten respondents indicated better working conditions in Norway, meaning: higher income, stable contract, etc., as a reason in favour of settlement in Norway, and every second participant pointed out 'no prospects in Poland', as a push factor.

\begin{tabular}{|l|l|}
\hline \multicolumn{2}{|l|}{ Table 6: Evaluation of respondents' family situation after migration } \\
\hline How do you evaluate your family's situation? & Frequency \\
\hline Very good & $238(37 \%)$ \\
\hline Good & $310(48 \%)$ \\
\hline Difficult to say & $94(15 \%)$ \\
\hline Bad & $4(0 \%)$ \\
\hline Very bad & $2(0 \%)$ \\
\hline Total & $648(100 \%)$ \\
\hline Source: Transfam's web survey \\
\hline
\end{tabular}

\section{Conclusions}

Polish migrants constitute the biggest group of immigrants in Norway, standing at the beginning of 2018 at about one hundred thousand. Along with Polish community networks and a growing number of children, part of temporary migration has transformed from circular into permanent migration. It should also be stressed that the number of Polish children residing in Norway and the number of children born in Norway to Polish females are growing each year. At the beginning of 2018, approximately 19 thousand Polish children - 15 years old and younger - resided in Norway. It means that their number has more than doubled when compared to 2010. Regarding births given yearly to Polish mothers, their number has changed from less than twelve hundred in 2010 to more than sixteen hundred in 2017. The process among Polish migrants of pioneering male migration followed by a family reunification seems similar to that observed in Polish migration to the UK studied by White (2011). It shall also be stressed that Transfam's findings confirm results from earlier studies indicating that processes of migration and adaptation of Polish migrants in Norway are better explained in terms of different stages in the migratory process rather than in terms of different categories of migrants (Friberg, 2012a).

\section{References}

Åström, J., \& Westerlund. O. (2009). Sex and Migration: Who is the Tied Mover? Umeå Economic Studies No. 787, 1-25.

Castles, S., Haas, H. D., \& Miller, M. J. (2014). The age of migration: International population movements in the modern world. Basingstoke: Palgrave Macmillan.

Cohen, R., \& Vertovec, S. (1999). Introduction. In S. Vertovec \& R. Cohen (Eds), Migration, diasporas and Transnationalism (pp. 13-28). Cheltenham, UK: Edward Elgar

Cooke, T. J. (2013). All tied up: Tied staying and tied migration within the United States, 1997 to 2007. Demographic Research,29, 817-836. doi:10.4054/demres.2013.29.30 
DaVanzo, J. (1981). Repeat migration, information costs, and location-specific capital. Population and Environment, 4(1), 4573. doi:10.1007/bf01362575

Faist, T. (2002). The volume and dynamics of international migration and transnational social spaces. Oxford: Clarendon Press.

Friberg, J. H. (2012a). Culture at work: Polish migrants in the ethnic division of labour on Norwegian construction sites. Ethnic and Racial Studies, 35(11), 1914-33. doi:10.1080/01419870.2011.605456

Friberg, J. H. (2012b). The 'Guest-Worker Syndrome' Revisited? Nordic Journal of Migration Research, 2(4), 316-324. doi:10.2478/v10202-012-0002-z

Friberg, J.H., Tronstad, Rose K., \& Dølvik, J.E. (2012). Central and Eastern European labour migration to Norway: Trends, conditions and challenges. In Free movement of workers and labour market adjustment: Recent experiences from OECD countries and the European Union (pp. 147-172). Paris: OECD Publishing. doi:doi.org/10.1787/9789264177185-en.

Gmaj, K. (2016). Settling in Norway? The case of Polish migrants and their families, Myśl Ekonomiczna i Polityczna, 2 (53), 163-191.

Gmaj, K. (2018). „Oswajanie” Norwegii - Wzory osiedleńcze polskich migrantów w Norwegii, Studia Migracyjne-Przegląd Polonijny, 1/2018, 163-191.

Iglicka, K. (2008). Kontrasty migracyjne Polski. Wymiar transatlantycki. Warszawa: Scholar.

Iglicka, K. (2010). Powroty Polaków po 2004 roku. W pętli pulapki migracji. Warszawa: Scholar.

Iglicka, K., Gmaj, K., Wierzejski, A. (2016). The Poles in Norway - we wanted workers but people arrived. Myśl Ekonomiczna i Polityczna. 1 (52): 116-138

Iglicka K., Gmaj K., Wierzejski A. (2018.) Contextualizing Polish Migration to Norway in the light of theory, statistical data and research findings. In K. Slany, P. Pustulka,E. Guribye, M. Ślusarczyk (Eds), Transnational Polish families in Norway: Social capital, integration, institutions and care. Frankfurt am Main: New York: Peter Lang.

Mincer, J. (1978). Family Migration Decisions. Journal of Political Economy, 86(5), 749-773. doi:10.1086/260710

Polachek, S., \& Horvath, F. (1977). A life cycle approach to migration: analysis of the perspicacious peregrinator. In R. Ehrenberg (ed). Research in labor economics. Greenwich, CT: JAI Press.

Portes, A., Guarnizo, L. E., \& Landolt, P. (1999). The study of transnationalism: Pitfalls and promise of an emergent research field. Ethnic and Racial Studies, 22(2), 217-237. doi:10.1080/014198799329468

Sassen, S. (2005). The global city: introducing a concept. Brown Journal of World Affairs, 11(2), 27-43.

Sjaastad, L. A. (1962). The Costs and Returns of Human Migration. Journal of Political Economy, 70(5, Part 2), 80-93. doi: $10.1086 / 258726$

Thorud, E. (2014). International Migration 2013-2014. IMO report for Norway. Oslo: Norwegian Ministry of Education and Research, Norwegian Ministry of Children, Equality and Social Inclusion, Norwegian Ministry of Justice and Public Security, Norwegian Ministry of Labourhttps://www.regjeringen.no/globalassets/documents/norway---imo-report-2013-2014-final.pdf. Date of access 15.03.2018

Thorud, E. (2018). Immigration and Integration 2016-2017. Report for Norway. Oslo: Ministry of Justice and Public Security, Ministry of Education and Research, Ministry of Labour and Social Affairs, Ministry of Children and Equality, Norwegian Ministry of Foreign Affairs. https://www.regjeringen.no/contentassets/005e1d69ad5141958451b8770552dab9/immigrationand-integration-20162017.pdf. Date of access 15.03.2018

White, A. (2011). Polish families and migration since EU accession. Bristol: Policy Press.

Home. (n.d.). Retrieved March 30, 2018, from https://www.ssb.no/en/ 